\title{
Hepatitis B and C Viral Infections among prisoners: Prevalence and Associated Risk Factors
}

Gaafar M. Abdel- Rasoul ${ }^{1}$, Reda A. Ibrahem ${ }^{1 *}$, Mahmoud A. Abo Salem ${ }^{1}$, Wessam S. Mourad ${ }^{2}$

${ }^{1}$ Department of Public Health and Community Medicine, Faulty of Medicine, Menoufia University, Egypt

${ }^{2}$ Department of Environmental Health of Liver, National Liver Institute, Menoufia University, Egypt

\begin{abstract}
:
Back ground: Blood borne diseases are generally higher in prisons than in the community as prisoners in jails usually come from low social class. Understanding the risk factors of hepatitis B viral (HBV) and hepatitis $\mathrm{C}$ viral (HCV) infections among prisoners could help improve their interventions. Objectives: This study aimed to estimate the prevalence of HBV and HCV infections among prisoners and to determine associated risk factors in the prison environment. Methods: A total number of 324 prisoners, who were incarcerated in Shebin Elkom general prison, were included in this study. Questions about personal data and risk factors for blood born infections were asked and all subjects were investigated for hepatitis B core antigen and hepatitis $\mathrm{C}$ antibody. Results: Among prisoners, the prevalence of HBV, HCV infections, and HBV/ HCV co-infections were $8.02 \%, 16.4 \%$ and $1.9 \%$ respectively. The $\mathrm{HBV}$ and $\mathrm{HCV}$ infections were significantly associated with history of tattooing, dental procedures and surgery. Using binary logistic regression model, it was shown that imprisonment duration and tattooing were independent risk factors for both HCV and HBV infections. Conclusion: Tattoos, use of shared personal tools and other circumstances that facilitate blood contact, which is especially present in prisons, increase HBV and $\mathrm{HCV}$ infection risk among prisoners. These results should promote consideration of routine HBV and HCV screening and behavioral interventions among the incarcerated.
\end{abstract}

Keywords: prevalence, HCV, HBV, co-infection, prisoners

Introduction: Hepatitis B viral (HBV) and C Viral (HCV) infections are major health problems in

Egypt. Many Egyptian studies proved that HBV infection is of intermediate endemicity, with 3-5\% of the population chronically infected, but $\mathrm{HCV}$ infection records a high endemicity. These infections lead to a particularly high morbidity and mortality. ${ }^{(1,2)}$ Blood born diseases (including HBV and HCV infections) are generally more frequent in prisons than in the community. ${ }^{(3,4)}$ These high prevalence can be mostly attributed to conditions often experienced by prisoners before incarceration such as: unsafe lifestyles, psychiatric and social problems.

Intravenous drug use (IVDU), tattooing and promiscuous sexual contact are the main risk factors for such blood born infections. ${ }^{(5)}$ Once in prison, overcrowding, violence, separation from family and emotional problems are additional reasons that may induce inmates to start or continue unsafe habits. ${ }^{(6)}$ The United Nations stated in the principles for the treatment of prisoners document that "prisoners shall have access to the health services available in the country without discrimination"

(7). The effects of intra-prison disease transmission are not limited to those that are incarcerated, as

Corresponding author: E mail: reda_8083@yahoo.com 
the risk for continued transmission extends to the general community to which the ex-offender returns. Thus, interventions addressing the prevention of infections in prisons affect the larger community. ${ }^{(8)}$

Unfortunately, the preventive programs are uncommonly applied in real life and in most countries prisoners have a lesser possibility of assistance and care than other citizens. ${ }^{(9)}$ In Egypt, the inmates suffer from scarcity of health services and care and also, few studies cover the epidemiological pattern of such infections in this risk group have been carried out to date. ${ }^{(10)}$

The identification of risk factors in this study and others can serve as a basis for developing a comprehensive strategy to prevent the transmission of blood-borne pathogens in prisons particularly the most prevalent ones, HBV and HCV infections and raising public awareness and demands for safety and infection control standards in prisons. ${ }^{(11)}$ This study was conducted to determine the seroprevalence and the prison related risk factors of HCV and HBV infections among Egyptian inmates.

\section{Methods:}

Across-sectional survey study was conducted in Shebin El-kom public prison (Menoufia Governorate, Egypt) from June 2014 to May 2016. A total number of 750 prisoners had been incarcerated in this prison, after excluding the inmates who had been incarcerated for less than 12 months, trouble maker prisoners (bullies, disciplinary imprisoned), political and those who refused to participate the remaining 362 prisoners were recruited in this study. Among them, 38 prisoners were analyzed as a pilot study; so, the total enrolled prisoners was 324 (246 males and 78 females).

The study was approved by the Ethical Committee of Faculty of Medicine, Menoufia University, and an official approval letter was obtained from the Ministry of the Interior, National Security Sector before beginning of the study. The importance of this study and the provided questionnaire were explained to all included participants, and the selected prisoners were advised to participate voluntarily with assurance of their confidentiality. No incentives were offered to the participants.

The enrolled prisoners were subjected to a pre-designed questionnaire that included:

- Personal data (age, gender, Level of education, family income, family size, occupation, socioeconomic status and marital status).

- Risk assessment of exposure to $\mathrm{HBV}$ and $\mathrm{HCV}$ infections before incarceration, including history of previous hepatitis testing and the result of the test, past history of viral hepatitis infection manifestations, surgery, blood transfusion, family history of hepatitis and previous hepatitis vaccination. 
- Risk assessment of exposure to HBV and HCV infections after incarceration, including history of previous imprisonment, imprisonment duration, dental procedures, shaving method, availability of personal hygienic tools, history of surgical procedures or blood transfusion and if attending health education programs in prison.

- Clinical examination: It was done with the help of the prison physician who examined the prisoners for any manifestations of active hepatitis as presence of jaundice, hepatomegaly, lower limb edema and/or ascites.

- Laboratory investigations: HB core antigen was detected by immunoassays (AbbottLaboratories, N-Chicago, USA) and Anti-HCV antibody was measured using the newly developed double-antigen sandwich immune-assay (Wantai, Beijing, China) calibrated using WHO standards (NIBSC, UK).

- All prisoners under the study except those were previously known as positive for HBV or HCV (21 prisoners) were investigated in prison hospital laboratory.

\section{Statistical analysis:}

The collected data were tabulated and statistically analyzed by IBM personal computer using statistical package for social science (SPSS version 20) (Chicago,IL, USA).

The qualitative data was described as percentage (\%). To study association between two qualitative variables, Chi-square test $\left(\chi^{2}\right)$ was performed. Odds ratio was calculated to weight the risk of different studied risk factors and binary logistic regression was performed to determine the independent risk factors associated with $\mathrm{HBV}$ and $\mathrm{HCV}$ infections. A P-value of $<0.05$ was reflected as statistically significant.

\section{Results:}

This study was conducted on 324 prisoners from Shebin Elkom Public Prison, $67.3 \%$ of them were of age less than 40 years, the same percent was illiterate, $75.9 \%$ of them were males and 73.8\% was married. All male participants mentioned that shaving is done by prison barber without changing shaving equipment and there is no available personal hygienic tool (scissor, tooth brush). $100 \%$ of prisoners who attended the prison hospital documented the use of new disposable syringes when injected for medical indication, $80 \%$ of studied inmates take at least one previous health education sessions (Table-1). Among the studied group, the prevalence of HBV, HCV, and HBV and HVCV dual infection was $8.02 \%, 16.4 \%$, and $1.9 \%$ respectively (Table-2).

Compared to non-infected prisoners, $\mathrm{HBV}$ and $\mathrm{HCV}$ infected prisoners (85 cases) were significantly older age, Illiterate and married, while the infection was not affected by sex. Tattoo was a significant risk for $\mathrm{HBV}$ and $\mathrm{HCV}$ infections. A statistically significant association between post imprisonment risk factors and acquiring $\mathrm{HBV} / \mathrm{HCV}$ infections. Prisoners with history of previous imprisonment had nearly 5 times risk for acquiring viral hepatitis compared to those who 
imprisoned for the first time. Similarly, those with imprisonment duration more than 10 years have nearly 11 times risk of acquiring viral hepatitis than others. Prisoners with previous intra-prison dentist visit were nearly 4 times risky to acquire viral hepatitis and prisoners with positive history of intra prison surgery carried nearly 5 times risk for acquiring viral hepatitis (Table-3).

Multivariate regression analysis of risk factors of $\mathrm{HBV}$ and $\mathrm{HCV}$ infection among prisoners showed that previous imprisonment history, education status, age, history of tattoo, history of intraprison dentist visiting, prolonged imprisonment duration(10 years or more) were independent predictors of viral hepatitis infection among prisoners with odds ratio $(6.83,4.24,2.96,2.95,2.81$, 2.57) respectively, while marital status and history of previous intra-prison operation were dependent predictors of viral hepatitis infection among prisoners (Table-4).

\section{Discussion:}

Concerns exist that prisons could serve as reservoirs that could intensify transmission of infectious diseases in the wider community as inmates who become infected behind bars are released. Such reservoirs would be formed by the high prevalence of infections such as HBV and HCV infections among inmates, particularly those with a history of injection drug use. In the general community, injection drug users have elevated rates of HBV and HCV infections compared with the general population. ${ }^{(8)}$ In the current study, prevalence of HBV, HCV and dual B \& C infection was $8.02 \%, 16.4 \%$ and $1.9 \%$ respectively.

These results are higher than that recorded for general Egyptian population by the Egyptian demographic and health survey (EDHS) in 2015 which stated that sero-prevalence for HBc antibody, $\mathrm{HBsA}$ and $\mathrm{HC}$ antibody were $9.9 \%, 1.0 \%$ and $6.3 \%$ respectively; with a significantly high rate of both infections were among male population $(11.3 \%, 1.2 \%$ and $7.5 \%$ respectively) than Egyptian females $\left(8.7 \%, 0.8 \%\right.$, and $5.3 \%$ respectively). ${ }^{(12)}$ The prevalence of HCV infection was higher, however, the HBV seems to be similar (8.02\% and 9.9\%). However, this similarity in HBV is not true as our study evaluated the seroprevalence of $\mathrm{HB}$ core antigen which indicate recent acute infection, while the test done in EDHS samples was HBc antibody which indicate previous or ongoing infection. ${ }^{(13)}$

The current study showed that $80 \%$ of infected prisoners were males. This male superiority in the prevalence of HBV and HCV infections was documented also in general population EDHS. ${ }^{(12)}$ This could be attributed to the incorporation of men in more risky behavior than women. Nearly 
similar prevalence was found by Mohamed et al, $2013^{(10)}$ who reported that the prevalence of hepatitis $\mathrm{C}$ virus antibodies was $15.8 \%$ and the prevalence of antibodies to hepatitis B core antigen was $9.8 \%$ and $1.2 \%$ of prisoners were dually infected with $\mathrm{HBV}$ and $\mathrm{HCV}$ in another Egyptian prison.

Similar results were reported among the prisoners in Turkey by Keten et al, 2016 $6^{(14)}$ who found that Anti-HCV was positive in $17.7 \%$ but it was higher regarding our $\mathrm{HBc}$ antigen seroprevalence as it showed $2.6 \% \mathrm{HBsAg}$ positivity. Adjei et al, $2006^{(15)}$ revealed similar seroprevalence of $\mathrm{HCV}(19.0 \%)$ while the $\mathrm{HBsAg}$ recorded $17.4 \%$ in prisons in Ghana, the difference in the prevalence of $\mathrm{HBV}$ may be attributed to the difference in the marker used for diagnosis. In France, Roux et al, $2014{ }^{(16)}$ reported a significantly higher prevalence of HCV in inmates $(5 \%)$ than in general population $(2 \%)$.

Surprisingly, an Iranian study ${ }^{(17)}$ reported extremely low level of $\mathrm{HBV}$ as $\mathrm{HBs} \mathrm{Ag}, \mathrm{HBc} \mathrm{Ab}$ and HBs antibodies were detected in $(0.63 \%),(0.63 \%)$ and $(32.5 \%)$ respectively which indicate very low level of infection and high immunity level among prisoners. this can be clarified as this study was done on juvenile prisoners which was vaccinated during childhood, this is the reason of elevated percentage of $\mathrm{HBs} \mathrm{Ab}$ among those prisoners. This finding supports the importance of $\mathrm{HB}$ viral vaccine in reducing the risk for such infection. Our findings proved that tattoo, long duration of imprisonment and dental and surgical procedures in the prison were risk factors for acquiring for viral hepatitis $\mathrm{B}$ and $\mathrm{C}$ infections.

Mohamed et al, $2013^{(10)}$ documented that the best predictor for hepatitis $\mathrm{C}$ and hepatitis $\mathrm{B}$ infections were intravenous drug use, longer duration spent in prison (>10 years) and shared toiletries. Different results were found by Roux et al, $2014^{(16)}$ whose study revealed that drug injection without snorting' and 'drug injection with snorting' were very strongly associated with HCV seropositivity. Among inmates, 'drug snorting alone' (OR (95\% CI) 2.21 (1.39 to 3.52) was also a strong correlate while tattoos, piercings (OR (95\% CI) 1.22 (0.92 to 1.61)) and the sharing of toiletry items (OR $(95 \% \mathrm{CI}) 1.44$ (0.84 to 2.47)) were weak correlates. This difference can be explained by the fact that each community had specific characters in relation to its prevalent disadvantageous behavior.

Study Limitation: We cannot extrapolate the obtained results because these results reflect only Shebin Elkom general prison. 


\section{Conclusion:}

Prisoners are vulnerable group with high rate of exposure to many diseases especially blood born categories due to relevant factors to their behavior and also security measures obliged in the prison that hinder the personal care and infection control measures with lack of optimum health facilities much lower than general population. Prisoners if not detected and treated will be major risk for other prisoners, prison officer and also the community after their release. Optimum surveillance program and vaccination of HBV negative inmates with frequent health education programs for prisoners and jail officers should be introduced as a trial to control this problem.

Conflict of interest: No conflict of interest was addressed

\section{References:}

1. Medhat, A, Shehata M, Magder L.S, Mikhail N, Abdel-Baki L, Nafeh M et al. Hepatitis C in a community in Upper Egypt: risk factors for infection. American Journal of Tropical Medicine and Hygiene. 2002; 66: 633-638

2. Khaled IA, Mahmoud OM, Saleh A F, Baioumi E A. Prevalence of HBV Genotypes in Egypt among Hepatitis Patients. Journal of American science. 2010; 6 (11): 186 - 190

3. Larney S, Kopinski H, Beckwith CG, Zaller ND, Jarlais DD, Hagan H, et al. Incidence and prevalence of hepatitis $\mathrm{C}$ in prisons and other closed settings: results of a systematic review and meta-analysis. Hepatology. 2013;58:1215-1224. [PMC free article] [PubMed]

4. Weinbaum CM, Sabin KM, Santibanez SS. Hepatitis B, hepatitis C, and HIV in correctional populations: a review of epidemiology and prevention. AIDS. 2005;19 (S3): S41S46. [PubMed]

5. Vescio MF, Longo B, Babudieri S, Starnini G, Carbonara S, Rezza G, et al. Correlates of hepatitis $\mathrm{C}$ virus seropositivity in prison inmates: a meta-analysis. J Epidemiol Community Health. 2008;62:305-313. [PubMed]

6. De Viggiani N. Unhealthy prisons: exploring structural determinants of prison health. Sociol Health Illn. 2007;29: 115-135. [PubMed]

7. United Nations. Basic principles for the treatment of prisoners. 1990. [Accessed 2015 Jan 10] Available at http://www.un.org/documents/ga/res/45/a45r111.htm last accessed Jan 7 2018.

8. Macalino GE, VlahovD, Sanford-Colby S. Prevalence and incidence of HIV, hepatitis B virus, and hepatitis $\mathrm{C}$ virus infections among males in Rhode Island prisons. American Journal of Public Health. 2004; 94: 1218-1223 
9. Bretschneider W, Elger BS. Expert perspectives on Western European prison health services: do ageing prisoners receive equivalent care? J Bioeth Inq. 2014;11:319-332. [PubMed]

10. Mohamed HI, Saad ZM, Abd-Elreheem EM, Abd-ElGhany WM, Mohamed MS, Abd Elnaeem EA, et al. Hepatitis C, hepatitis B and HIV infection among Egyptian prisoners: seroprevalence, risk factors and related chronic liver diseases. J Infect Public Health. 2013 Jun;6(3):186 - 195. doi: 10.1016/j.jiph.2012.12.003.

11. Teutsch S, Luciani F, Scheuer N, Mc Credie L, Hosseiny P, Rawlinson W, et al. Incidence of primary hepatitis $\mathrm{C}$ infection and risk factors for transmission in an Australian prisoner cohort. BMC Public Health. 2010;10:633 - 638. doi: 10.1186/1471-2458-10-633. [PubMed]

12. Egyptian Demographic and Health Survey, 2015. Hepatitis B. Available at https://dhsprogram.com/what-we-do/survey/survey-display-480.cfm Last retrieved December 15, 2017

13. Trépo C, Zoulim F, Alonso C, Petit M A, Pichoud C, Vitvitski L. Diagnostic markers of viral hepatitis B and C. Gut, 1993; 34(2 Suppl): S20-S25.

14. Keten D, Ova ME, Keten HS, Keten A, Gulderen E, Tumer S, et al. The Prevalence of Hepatitis B and C Among Prisoners in Kahramanmaras, Turkey. Jundishapur J Microbiol. 2016; 9(2): e31598 - e31602. doi: 10.5812/jjm.31598, PMC4842253

15. Adjei AA, Armah HB, Gbagbo F, Ampofo WK, Quaye IK, Hesse IF, et al. Prevalence of human immunodeficiency virus, hepatitis B virus, hepatitis $\mathrm{C}$ virus and syphilis among prison inmates and officers at Nsawam and Accra, Ghana. J Med Microbiol. 2006 May;55(Pt 5):593-597.

16. Roux P, Sagaon-Teyssier L, Lions C Fugon L, Verger P, Carrieri M P. HCV seropositivity in inmates and in the general population: an averaging approach to establish priority prevention interventions. BMJ. 2014;4:e005694. doi: 10.1136/bmjopen-2014-005694

17. Ataie M, Nokhodian Z, Ataei B, Kassaian N, Yaran M, Hassannejad R. Seroprevalence of hepatitis B virus and human immunodeficiency virus among young prisoners. J Res Med Sci. 2013 Jan; 18(1): 70-72. PMCID: PMC3719232 
Table (1): Socio demographic characteristics and prevalence of HBV \& HCV among the studied prisoners.

\begin{tabular}{|c|c|c|}
\hline & & oup \\
\hline & No & $\%$ \\
\hline Age & & \\
\hline - $<40$ & 218 & 67.3 \\
\hline - $\geq 40$ & 106 & 32.7 \\
\hline Gender & & \\
\hline - Male & 246 & 75.9 \\
\hline - Female & 78 & 24.1 \\
\hline Education & & \\
\hline - Illiterate & 218 & 67.3 \\
\hline - Educated & 106 & 32.7 \\
\hline Marital status & & \\
\hline - Married & 239 & 73.8 \\
\hline - Unmarried & 85 & 26.2 \\
\hline Pre imprisonment risk factors & & \\
\hline - Pre imprisonment surgery & 59 & 18.2 \\
\hline - Pre imprisonment blood transfusion & 9 & 2.8 \\
\hline - Tattoo & 93 & 28.7 \\
\hline - Family History of hepatitis & 19 & 5.9 \\
\hline Intra prison risk factor & & \\
\hline - History of Previous Imprisonment & 41 & 12.7 \\
\hline - Imprisonment Duration $\geq 10$ years & 53 & 16.4 \\
\hline - Shared toiletries & 324 & 100 \\
\hline - Intra prison dentist visiting & 121 & 37.3 \\
\hline - Intra prison surgery & 14 & 4.3 \\
\hline
\end{tabular}

Table(2): Seropravalence of HBV, HCV and dual infection

\begin{tabular}{|l|c|c|}
\hline & \multicolumn{2}{|c|}{ The studied group (N=324) } \\
\hline HBV positive cases & 26 & 8.02 \\
\hline HCV positive cases & 53 & 16.4 \\
\hline Dual infection & 6 & 1.9 \\
\hline
\end{tabular}


Table (3) Association between of anti-HBc and/or anti-HCV positivity and socio-demographic data among the studied prisoners:

\begin{tabular}{|c|c|c|c|c|c|c|c|}
\hline \multirow[t]{3}{*}{ Socio demographic data } & \multicolumn{4}{|c|}{ Viral hepatitis B\&C } & \multirow{3}{*}{$\chi^{2}$} & \multirow{3}{*}{$\begin{array}{c}\mathrm{P} \\
\text { value }\end{array}$} & \multirow{3}{*}{$\begin{array}{c}\text { OR } \\
\text { (CI 95\%) }\end{array}$} \\
\hline & \multicolumn{2}{|c|}{ Positive } & \multicolumn{2}{|c|}{ Negative } & & & \\
\hline & $\mathrm{N}=85$ & $\%$ & $\mathrm{~N}=239$ & $\%$ & & & \\
\hline $\begin{array}{r}\text { Age /years } \\
-\quad<40 \\
-\quad \geq 40 \\
\end{array}$ & $\begin{array}{l}35 \\
50 \\
\end{array}$ & $\begin{array}{l}41.2 \\
58.8\end{array}$ & $\begin{array}{c}183 \\
56 \\
\end{array}$ & $\begin{array}{l}76.6 \\
23.4 \\
\end{array}$ & 35.68 & 0.001 & $\begin{array}{c}4.668 \\
(2.67-8.18) \\
\end{array}$ \\
\hline $\begin{array}{c}\text { Gender: } \\
\text { - } \quad \text { Male } \\
\text { - Female }\end{array}$ & $\begin{array}{l}68 \\
17\end{array}$ & $\begin{array}{l}80.0 \\
20.0\end{array}$ & $\begin{array}{c}178 \\
61\end{array}$ & $\begin{array}{l}74.5 \\
25.5\end{array}$ & 1.05 & 0.376 & $\begin{array}{c}1.37 \\
(0.72-2.63)\end{array}$ \\
\hline $\begin{array}{c}\text { marital status: } \\
\text { - Unmarried } \\
\text { - Married }\end{array}$ & $\begin{array}{l}12 \\
73 \\
\end{array}$ & $\begin{array}{l}14.1 \\
85.9\end{array}$ & $\begin{array}{c}73 \\
166 \\
\end{array}$ & $\begin{array}{l}30.5 \\
69.5 \\
\end{array}$ & 8.74 & 0.003 & $\begin{array}{c}2.68 \\
(1.32-5.54) \\
\end{array}$ \\
\hline $\begin{array}{c}\text { Education state: } \\
\text { - Illiterate } \\
\text { - Educated }\end{array}$ & $\begin{array}{l}46 \\
39 \\
\end{array}$ & $\begin{array}{l}54.1 \\
45.9\end{array}$ & $\begin{array}{c}172 \\
67\end{array}$ & $\begin{array}{l}72.0 \\
28.0\end{array}$ & 9.07 & 0.003 & $\begin{array}{c}2.18 \\
(1.26-3.75)\end{array}$ \\
\hline $\begin{array}{l}\text { Pre-imprisonment risk factor: } \\
\text { History of previous surgery } \\
\text { - No } \\
\text { - Yes } \\
\text { History of previous blood } \\
\text { transfusion } \\
\text { - No } \\
\text { - Yes } \\
\text { Tattoo } \\
\text { - No } \\
\text { - Yes } \\
\text { Family History of hepatitis } \\
\text { - No } \\
\text { - Yes }\end{array}$ & $\begin{array}{c}49 \\
36 \\
81 \\
4\end{array}$ & $\begin{array}{c}96.5 \\
3.5 \\
57.6 \\
42.4 \\
\\
95.3 \\
4.7\end{array}$ & $\begin{array}{c}182 \\
57 \\
\\
224 \\
15\end{array}$ & $\begin{array}{c}97.5 \\
2.5 \\
76.2 \\
23.8 \\
\\
93.7 \\
6.3\end{array}$ & $0.28 *$ & 0.001 & $\begin{array}{c}1.74 \\
(0.92-3.27) \\
1.42 \\
(0.27-6.58) \\
2.35 \\
(1.39-3.96) \\
\\
0.74 \\
(0.2-2.47)\end{array}$ \\
\hline $\begin{array}{l}\text { Intra prison risk factor: } \\
\text { History of Previous } \\
\text { Imprisonment }(\mathrm{N}=41) \\
\text { - No } \\
\text { Imprisonment Duration: } \\
\text { Impris } \\
\text { - } \geq 10 \text { years } \\
\text { Intra prison dentist visiting } \\
\text { - No } \\
\text { - Yes } \\
\text { Intra prison surgery: } \\
\text { - No } \\
\text { - Yes }\end{array}$ & $\begin{array}{l}62 \\
23 \\
48 \\
37\end{array}$ & $\begin{array}{l}72.9 \\
27.1 \\
\\
56.5 \\
43.5 \\
\\
36.5 \\
63.5 \\
\\
\\
89.4 \\
10.6 \\
\end{array}$ & $\begin{array}{c}221 \\
18 \\
\\
223 \\
16\end{array}$ & $\begin{array}{c}92.5 \\
7.5 \\
\\
93.3 \\
16 \\
\\
72.0 \\
28.0 \\
\\
97.9 \\
2.1 \\
\end{array}$ & 62.18 & $\begin{array}{l}0.001 \\
0.001 \\
0.001 \\
0.003\end{array}$ & $\begin{array}{c}4.55 \\
(2.2-9.48) \\
\\
10.74 \\
(5.28-22.09) \\
4.47 \\
(2.56-7.82) \\
5.54 \\
(1.63-19.69) \\
\end{array}$ \\
\hline
\end{tabular}


Table (4) Binary logistic regression analysis for independent risk factors of $\mathrm{HBV}$ and $\mathrm{HCV}$ infections among prisoners

\begin{tabular}{|c|c|c|c|c|c|}
\hline Variables & $\mathrm{B}$ & S.E. & $\begin{array}{l}\text { Wald } X^{2} \\
\text { test }\end{array}$ & $\begin{array}{l}\mathrm{p}- \\
\text { value }\end{array}$ & $\begin{array}{l}\text { OR } \\
\text { (CI 95\%) }\end{array}$ \\
\hline - Age & 1.085 & 0.35 & 9.34 & 0.002 & $2.96(1.48-5.93)$ \\
\hline - $\quad$ Marital status & 0.779 & 0.42 & 3.42 & 0.065 & $2.18(0.95-4.98)$ \\
\hline - Education state & 1.45 & 0.37 & 15.58 & 0.0001 & $4.24(2.07-8.69)$ \\
\hline - $\quad$ Tattoo & 1.08 & 0.36 & 8.89 & 0.003 & $2.95(1.45-6.02)$ \\
\hline - Previous Imprisonment & 1.92 & 0.43 & 19.60 & 0.0001 & $6.83(2.92-15.98)$ \\
\hline - Imprisonment Duration & 0.94 & 0.21 & 21.10 & 0.0001 & $2.57(1.72-3.85)$ \\
\hline - History of dentist visiting & 1.03 & 0.34 & 9.22 & 0.002 & $2.81(1.44-5.46)$ \\
\hline $\begin{array}{l}\text { - History of previous intra_ } \\
\text { prison surgery }\end{array}$ & 1.43 & 0.82 & 3.05 & 0.081 & $4.18(0.84-20.83)$ \\
\hline
\end{tabular}

$\mathrm{SE}=$ standard error, $\mathrm{OR}=$ odds ratio, $\mathrm{CI}=$ confidence interval 


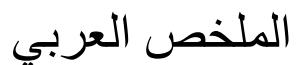

الالتهاب الكبدي الفيروسي "بي" و "سي" بين السجناء: مدي الانتشار و وعو امل الخطورة المصاحسبة

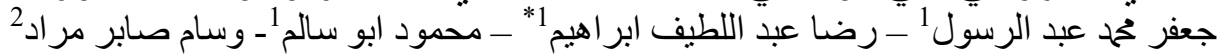

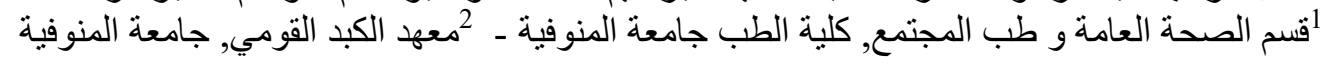

الخلفيه: تتميز الأمر اض المنقولة عن طريق الدم بمعدل أعلى في السجون عنه في المجتمع. إذ ان السجناء يأتون عادة من الفئات الدحرومة اجتماعيا وتعليميا، والتي تعاني من ضعف فرص الحصول على الرعاية الصحية بالاضافة الي انتشار سلوكيات مثل

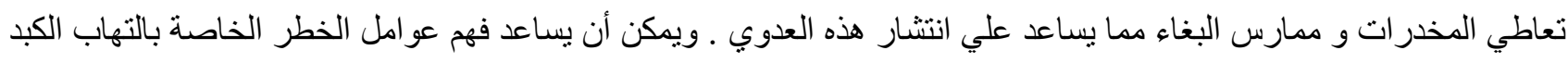

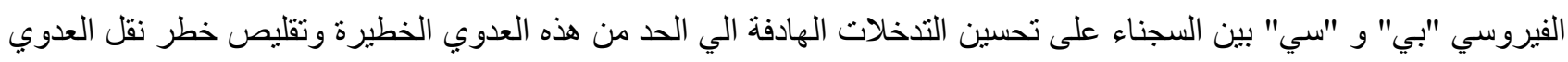

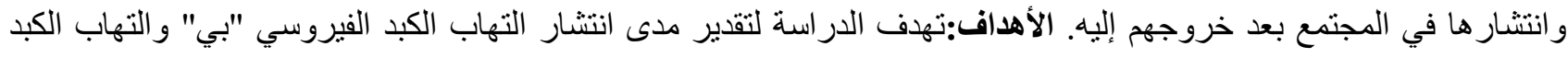
الفيروسي "سي" بين السجناء، وتحديد عوامل الخطر المرتبطة بها. المنهجيه وطرق البحث: وقد ضمت الدراسة 324 سجينا كانوا

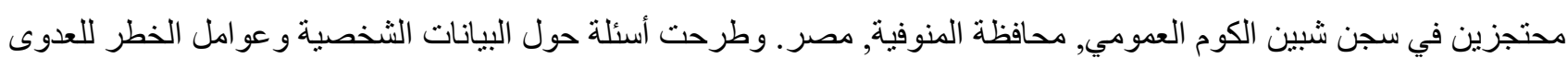

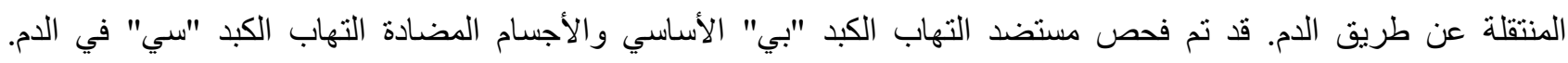

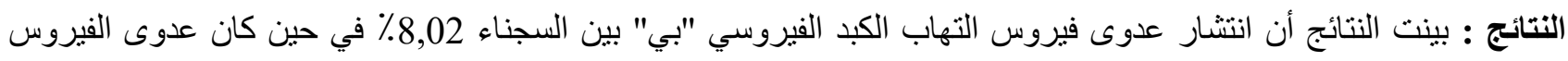

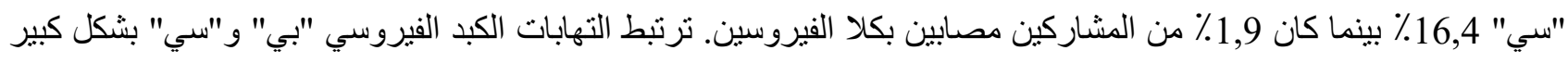

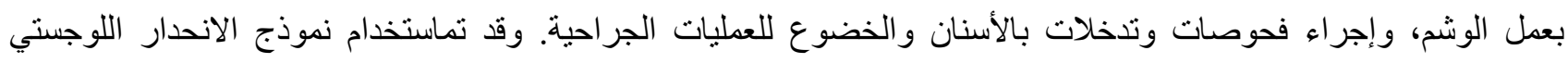
الثنائي، فتبين أن مدة البقاء بالسجن (10 سنوات أو أكثر) و عمل الوشم هى عوامل خطورة مستقلة لكل من التهاب الكبد الوبائي

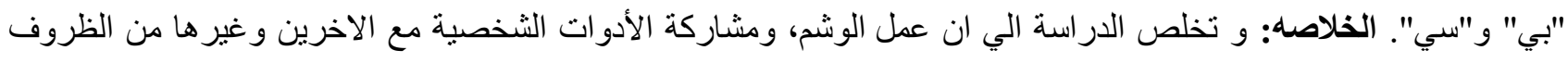

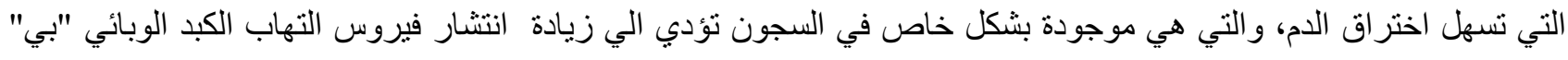

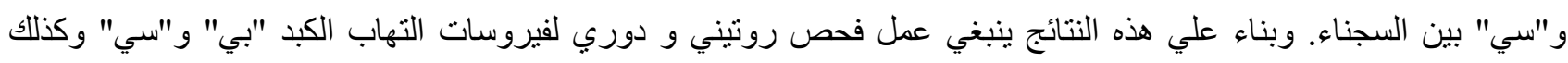
العمل علي تعديل الشاكل السلوكية بين السجناء. 